\title{
Do Working Women Contribute to Higher Consumption Expenditures? ${ }^{1}$
}

\author{
Wen JUN - Junaid WAHEED - Hadi HUSSAIN*
}

\begin{abstract}
Working women with their highly relative bargaining power and compulsive buying behavior can significantly affect household consumption expenditures. This study investigates the relationship between the number of working women and aggregate consumption expenditures. We examine the hypothesis that changes in the number of working women have a perceptible impact on per capita household consumption expenditures, by extension, on aggregate consumption. Using panel data for a set of The Organization for Economic Co-operation and Development (OECD) countries from 2000 - 2018, the outcomes of two-stage least squares and generalized method of moment estimations indicate that as the number of women increases, gross domestic consumption rises. The implied disparity in consumption propensities exists among different age groups of working women. These findings suggest the importance of considering working women's spending behavior and household decision-making in planning for the development of gross domestic consumption and output.
\end{abstract}

Keywords:working women, spending behavior, household expenditures, aggregate consumption, economic output, empirical analysis

JEL Classification: D12, D91, J16

DOI: https://doi.org/10.31577/ekoncas.2021.04.03

\section{Introduction}

Consumption is one of the fundamental components of gross domestic product and the main variable for measuring economic growth. In most countries, it counts for more than $60 \%$ of the gross domestic product (OECD, 2009). Since it

\footnotetext{
* Wen JUN - Junaid WAHEED, corresponding author - Hadi HUSSAIN, Xian Jiaotong University, School of Economics and Finance, 74 Yanta Road, 710000 Xian, China; e-mail: wjun1978@163.com; junaidwaheed@stu.xjtu.edu.cn; hussainhadi@stu.xjtu.edu.cn

${ }^{1}$ All authors are jointly acknowledged for the research strategies of this paper.
} 
accounts for a large amount of the national income, understanding the dynamics of consumption expenditures is crucial to understanding macroeconomic fluctuations and economic growth (Gerstberger and Yaneva, 2013). A large number of studies discuss and measure the classic dynamics of aggregate consumption (some pertinent studies include (Weber, 1970; Cushing, 1991; Delgado and Miles, 1997; Mehra, 2001; Chatterjee, 2009; Lahiri, Monokroussos and Zhao, 2015). However, the debate on the factors affecting consumption expenditures shifted from Keynesian capacity-to-consume determinants to the effects of individual characteristics, demographic structure, and welfare policies.

One of the least discussed topics is the position of gender in influencing household consumption expenditures. Therefore, further exploration of the relation between working women's spending behavior and aggregate consumption is required. Women's compulsive buying and relative bargaining power are likely to affect the family's consumption expenditures (Manchanda, 2012). With their dissimilar social and economic status within and outside the home, women's spending behavior is quite different from men's. Women, due to the higher marginal propensity to consume, are considered relatively strong consumers (Kornrich and Roberts, 2018).

In the last few decades, the proportion of working women has increased enormously in most parts of the world. ${ }^{2}$ Due to the improvement in education levels and socioeconomic status, women are becoming equal participants to men in various occupations (Buvinic and Furst-Nichols, 2014). The implication of this social development brought a substantial change in their family needs and lifestyle patterns. Working women, with their high purchasing power (Roberts, 2014), are acknowledged as more imprudent in their spending decisions. Thus, investigating the effect of working women's spending behavior on household consumption expenditures is crucial for the micro/macroeconomic perspective of the economy.

This paper confers the theoretical substantiation to decide whether there are differences in the spending behavior of working women that affect household consumption expenditures. Simultaneously, it also empirically estimates the effects of changes in the number of working women on aggregate household consumption expenditures. Theoretically, working women's spending behavior has a positive effect on personal and household consumption expenditures, as evidenced by the arguments in the next sections. Additionally, data analysis proves these concepts empirically. The models estimated here employ real per capita aggregate consumption as the dependent variable, measuring gross consumption

\footnotetext{
${ }^{2}$ Worldwide, women control about 20 trillion USD in annual aggregate consumer expenditures and this number could rise as high as 28 trillion USD in the next five years (Ipsos, 2018).
} 
expenditure factors, including income. Using a panel data set of the Organization for Economic Co-operation and Development (OECD) countries allows us to investigate the effects of shifts in the number of working women on consumption expenditures over time within as well as across countries. The model equation estimated through two-stage least squares (2SLS) and generalized method of moments (GMM) indicates a positive relationship between the number of working women and per capita household consumption expenditures. Particularly, the estimated results show that age plays an important role in working women's decision-making about spending, which in turn ultimately affects household consumption expenditures. The research explores how working women's buying behavior, with their employment and income, is beneficial for the economic outcomes by affecting aggregate consumption expenditures.

\section{Theoretical Framework}

\subsection{Working Women's Spending Behavior}

In recent years, women are financially independent in most parts of the world. ${ }^{3}$ The financial self-sufficiency of the women strengthens their ability to make independent decisions based on personal and household consumption expenditures by allowing them to have a relatively high bargaining power to spend money. Besides this, there are several other reasons why working women spend larger proportions of their income. Compulsive shopping behavior makes working women spend more of their income (Manchanda, 2012). One assumption is that working women will be more intrigued by efficient items and services, such as take-out suppers, instant dusting sprays, fashionable clothing, and cleaning services. The time limitations of the daily schedule of family tasks including cooking, cleaning, and grocery shopping, suggest that different strategies are most likely to be implemented to manage these tasks (Cupak, Porkrivcak and Rizov, 2016). The differences in attitudes among working and non-working women concerning female roles are likely to manipulate their consumption behavior. The dual roles of females in their jobs and at home will require a different degree of participation in homemaker responsibilities compared to non-working women, for whom such things are considered as the main duties (Shotick, 2015). Instead of avoiding and not fulfilling their homemaker tasks, working women search for other means of self-fulfillment in activities in and outside of the home (Keng and Lin,

\footnotetext{
${ }^{3}$ According to the 2019 report of CNBC, it is expected that about $90 \%$ of women will have to finance themselves solely with their earnings at some point in their lives. The report further states that compared to 51 trillion USD spent in 2015, global wealth controlled by women increased up to 72 trillion USD, or $32 \%$ in 2020 .
} 
2005). As the time and effort dedicated to homemaker roles may be different from those of non-working women, they will try their best to cope with it with their earnings (Killewald, 2011). Thus, spending money on these extra products and services in working women families increases their overall household consumption expenditures.

More to the point, a working woman's lifestyle is relatively different from the non-working one. They spend more money on their grooming, clothing, and other assets. The consequences of a different lifestyle pattern on working women's spending behavior are vast (Anderson and Eswaran, 2009; Lancaster, Pushkar and Ranjan, 2008).

\subsection{Decision-making in Different Age Groups}

If we imply the channels explained in the above section for spending behavior of working women in different age groups, there will be considerable differences between each of their buying behaviors. Women's spending behavior in a certain period is much unlike the other (Addessi, 2018). In general, young working women are considered as more compulsive buyers compared to middleaged and older women. They spend more on their grooming and clothing. However, middle-aged and older working women spend more on household expenditures such as house furnishings, recreational family trips, and extra services for the household. DeWeese and Norton (1991) empirically proved that working wives raise consumption expenditures on household necessities such as clothing, children's education, non-durable items, etc. Working women tend to be more efficient in organizing household tasks according to their income; they spend more on services to save time and are more likely to be accompanied by their family (Lee, Jinkook and Yunhee, 2011). Conversely, there are research studies that found little support for this point such as Bhupal and Sam (2014) who stated that there is little evidence of working women being more concerned about convenience products than non-working women. Such studies do not provide comprehensive information and hardly scrape the surface of working women's spending manners.

\subsection{Working Women and Gross Consumption Expenditures}

If working women influence the family's spending patterns by implication, ${ }^{4}$ there may be an imperative impact on macroeconomic factors. Women's access to outside income is likely to raise household spending and ultimately the gross

\footnotetext{
${ }^{4}$ Macroeconomic variables are the total values of the economic indicators collected at the household level throughout the specific region. Thus, a change in household-level measured indicators will ultimately bring a change in aggregate indicators.
} 
consumption. In the last few decades, due to an enormous increase in the proportion of working women, economic activity has improved extensively (Raz-Yurovich, 2010). Females' participation in work outside of the house leads to higher growth of economic factors (Jun et al., 2020). The countries with a higher proportion of working women contribute significantly to consumption expenditures. Theoretically, working women have conflicting and thus ambiguous effects on gross consumption expenditures, but one empirical study showed that women contribute about 70 to 80 percent of the overall consumer expenditures (Wamoyi et al., 2020). To understand the concept on an extensive level, it would be better to do a macro-level analysis investigating the connection between the number of working and aggregate consumption expenditures.

Figure 1 represents the movement in the number of working women and per capita consumption in 35 OECD countries from 2000 to $2018 .^{5}$ It can be seen that there is an increasing trend in both of the series across the panel of the individual country. It appears that the number of working women is moving along with per capita consumption is a trend within the individual country throughout all of the years.

Figure 1

Trends in per capita Household Consumption of OECD Countries

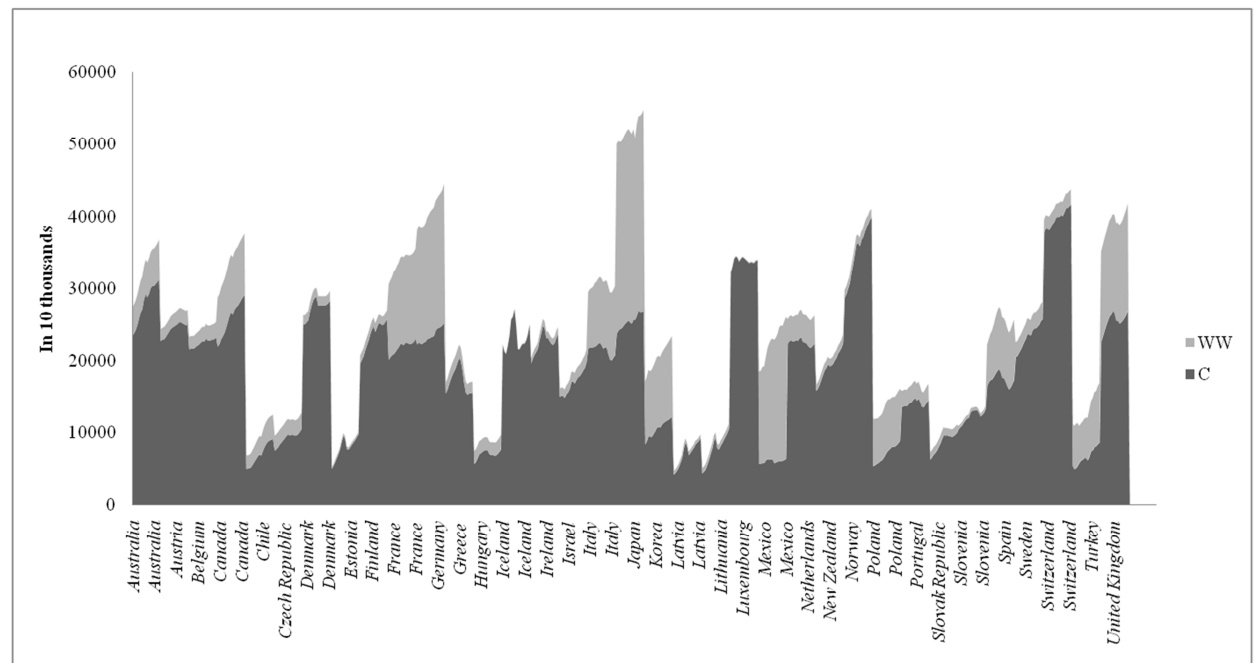

Source: OECD Statistics.

Figure 1 is representing the trends in the number of working women (in thousands) and household per capita consumption expenditures (in millions) in 35 OECD countries for the year $2000-2018$.

\footnotetext{
${ }^{5}$ Data Source; OECD statistics; <https://stats.oecd.org/>.
} 
Consumption is considered the most important component of the gross domestic product of a country. Thus, dynamics of consumption expenditures indicate a parallel movement in the path of economic growth. Understanding consumption dynamics through female participation in a field of work would be beneficial for economic growth policies.

\subsection{Objectives and Hypotheses}

The purpose of this research is to explore the impact of the changes on the number of working women per capita household consumption expenditures. This research paper explores the concept of how the number of working women affects household consumption expenditures, which in turn gives a drivable foundation for measuring per capita consumption expenditures of the country. Moreover, the study provides crucial findings for dissimilar age groups with different spending patterns. These findings propose that there ought to be suitable policy-making for each division within each group.

Based on the above explanations on the number of working women and their impact on per capita household consumption, we build these three hypotheses:

H1: Working women, due to their high bargaining power and compulsive spending behavior, have a significant effect on household consumption expenditures.

$\mathrm{H} 2$ : The age of working women affects their spending decisions and eventually overall household consumption expenditures.

H3: Increase in the number of working women is positively associated with an increase in per capita household consumption expenditures, and by extension, gross domestic consumption.

The rest of this study is structured as follows. Section 2 is a review of relevant previous studies and theories that are linked to the phenomenon of working women's consumption behavior and household consumption expenditures. Section 3 explains the descriptive statistics which are later used in empirical estimations. Section 4 presents the methodologies and estimations. The results of estimated models through different econometric techniques are also explained in this section. Section 5 presents the discussion and policy implication of this research. At the end we summarize the conclusion.

\section{Literature Review}

Limited attention has been paid to investigating the impact of women's employment status on buying behavior and on their consumption expenditures. Most literature on consumer spending examines all households as combined 
decision-making individuals with common preferences and collective incomes. For example, studies of Chen and Woolley (2001), Bonke (2010), and D'Aspremont and Ferreira (2019) support the expansion of the collective model of household expenditure patterns. However, many studies reject this 'income pooling' hypothesis (e.g., Lee and Pocock, 2007; Browning, Pierre-Andre and Arthur, 2013; Watson and Wooden, 2013; Beblo and Beninger, 2012).

Women's labor force participation brings a considerable increase in expenditures for housekeeping, child care, and gardening services (Kornrich and Roberts, 2018). Working women use their ability to gain higher bargaining power and manage economic resources to increase household spending on food (Schmeer, 2005). Household production variables have a major impact on service expenses (Soberon-Ferrer and Dardis, 1991). Families with full-time and part-time working women spend more on food away from home, child care, and total services. According to Bodur and Avci (2016), working women can affect household consumption expenditures in two ways. First, households will be more likely to replace home-made goods and services with marketed goods and services since women now have less time to spend on the household, and second, spending patterns of the family members will differ independently of the productive use of time on the home by these women. Both of these effects are related to the decision concerning work. Researchers such as Hoddinott and Haddad (1995), Phipps and Burton (1998), Browning and Chiappori (1998), Koolwal and Ray (2002), and Handa et al. (2009) explained the gender bias in the intrahousehold allocation of resources investigating the household's spending behavior on various goods and services within the framework constructed in the bargaining power models.

Working women are more stressed because of work pressure. They go shopping to offset work pressure. The research by Kukar-Kinney, Ridgway and Monroe (2009) states that females do impulsive purchasing to control negative feelings or to have good encounters to mitigate negative ones. They have achieved a "high" on the compulsive buying scale to overcome the strain of daily life. Working women show compulsiveness in shopping as they try to find substantiation or a sense of purpose via shopping and spending (Mueller, 2019). Indeed, shopping is a kind of relaxation for them. Considering this perspective, it may be presumed that working women's financial territory is not the only thing that makes them open to unreasonable purchasing inclinations, but also socialization. Joji and Raveendran (2008) state that credit card accessibility is likewise expected to be one of the reasons for overspending. Working women can apply for credit cards that give them additional buying power (Joireman, Kees and Sprott, 2010). The recent development in retail shopping centers and access to internet purchasing bring fuel to fire for the rising tendency to purchase more. 
Male and female income doesn't have the same impact on family consumption expenditures. One study found that married couples are more likely to utilize their profits for private consumption and spending on products used by the whole family reflected gendered circles of obligation (Phipps and Burton, 1998). Manchanda (2015) also found that there is a significant uniqueness in impulsive purchasing inclinations of working and non-working females. This research demonstrated that non-working women are less enthusiastic purchasers than working ones, while the degree of socialization may be one of the same variables. Women's representation affects expenditures on childcare, education, and elderly care (Svaleryd, 2009). Also, direct spending resulting from the employment of a female in the family includes clothing, transportation, and home services expenditures (Hanson and Ooms, 1991). Women's control over their income is mainly imperative for expanding food expenditure in low-income families (Schmeer, 2005). In richer families, women who have their income also use spouse income transfers to disburse food expenditures.

Women's employment status was significantly related to expenditure on food from outside restaurants, child care, and total services (Manrique and Jensen, 1998; Foster and Mammen, 1992; Handayani and Handayani, 2019). Families of part-time working women increased expenses on food away from the residence compared to households of full-time homemakers. Hopkins, Levin and Haddad (1994) used a gender-disaggregated cyclic consumption model to investigate whether the gender of an income earner or both manipulates the household's spending patterns at a given level of household income. The study found that the total family expenditures and the gender of the income-earner matters, given that the annual income is not pooled, and at the same time the overall income and the gender-specific income are significant measures of household consumption spending.

Bhupal and Sam (2014) measured the effect of women's income on children after a rise in income through the National Rural Employment Guarantee Scheme (NREGS) program in the United States. The research results showed that female income has a large increase in spending on children's clothing and other items. Men's income, based on the NREGS program, had no impact on children's expenses for the given categories.

Female labor contribution causes an increase in the consumption expenditure of several commodities based on visible household characteristics (Lee, Jinkook and Yunhee, 2014). An increase in the number of working women also causes changes in consumption expenditures that are undetected by us but are realistic and considered by the household at the time when it decides whether the women can work. 
In the past, researchers investigated several direct and indirect effects of women's earnings on household consumption expenditures. This paper adds to the previous literature by doing a detailed analysis of working women's buying behavior and its impact on per capita household consumption expenditure. The comprehensive research analysis incorporates buying behavior of different age groups of working women and their effects on consumption expenditure. The study fills some gaps in our perception of the relationship between working women and consumption expenditures.

\section{Data and Variables}

To perform our empirical analysis, 6 main variables are used for estimations. The independent variable consumption variable is approximated by the real total household per capita consumption expenditures. The independent variable or the working women variable includes the total number of employed women, the total number of young employed women, the total number of middle-aged employed women, and the total number of employed women. Other control variables include income approximated by actual net per capita national disposable income, inflation approximated by a consumer price index, population approximated by fertility rate, and purchasing power parity. Data on relevant variables are collected and combined from three different sources: OECD statistics, International Labor Organization (ILO) statistics, and World Bank Development Indicators. ${ }^{6}$ Data on working women variables are retrieved from ILO statistics and per capita, while household consumption expenditures are collected from World Bank Development Indicators. Other information on control variables is collected from World Development Indicators (WDI) and OECD websites. The selection of time and countries in the sample is determined by variation in size, arrangement, and regional dissimilarity of the countries. A panel data set of 36 OECD countries from 2000 to 2018 yielding 684 observations allows the collection of dynamic behavior information and a large sample's capacity of accurate estimates. A complete description of all of the variables is given below.

\subsection{Dependent Variables}

The consumption expenditures, as noted above, are approximated by the final household per capita consumption expenditures, which are measured in 2010 U.S. dollar prices for the sample countries. Household per capita final consumption

\footnotetext{
${ }^{6}$ Data collected from different sources are converted into the same units. The data on consumption and income series is used in per capita terms.
} 
expenditures are the market values of all products and services purchased by family units at a specific time. They exclude the acquisition of private housing; however, they incorporate the attributed lease for the proprietor's residences. This additionally incorporates installments and charges to governments to acquire permits and licenses.

Several studies such as those of Ibrahim and Habibullah (2010) and Fisher et al. (2020) have also used the household per capita final consumption expenditures as the consumption variable.

\subsection{Independent Variables}

The working women variable defines the total number of working women calculated annually for each country. The data is collected for full-time employed women. On average, people who usually work less than 35 to 40 hours per week are considered part-time workers. Women in part-time jobs, involuntary employment, or short-term work with economic fluctuations are not classified as fully employed workers. Thus, they are excluded from this category. Unpaid working women, in and outside of the family who work less than 15 hours per week, are also not classified in the employed women category. The data tables are taken from labor force statistics. The labor force data on employment by sex and by standard age groups are used as several working women. The working women variable is further expanded into three categories: 1 . The total number of employed women from the age of 15 to 34 years is classified as young working women. 2. The total number of employed women from the age of 35 to 54 years is classified as middle-aged working women. 3. The total number of employed women from the age of 55 years and above is classified as elderly working women. Each of these three is included in our analysis separately.

\subsection{Control Variables}

To get an accurate and robust result, we used other control variables including per capita income, inflation, population, and purchasing power parity in the regression analysis. The details are as follows.

According to Keynes' absolute income hypothesis, individuals' consumption is positively associated with their income. Permanent life cycle theory explains income and consumption defining income as the main determinant of consumption (Pischke, 1991). One must include an income variable in measuring consumption expenditures to control the income effect. Thus, we used per capita income approximated by net national income which is calculated by gross national income minus consumption of the fixed capital. It excludes natural resource 
diminution. Studies such as Battistin and Padula (2010) explored the relationship between population and consumption expenditure. Following their study, the fertility rate is used as the measure of the population in this research. Annual data is calculated from World Bank indicators.

Manasseh et al. (2018) explain that the reaction to inflation news causes an increase in the households' education level depending on the continuation of constraints on the household's capability to route this information. This leads to a change in consumer decision-making. Whereas, when the expected inflation rate could not be observed, the real consumption would be affected only by the judgment error of an unobservable price increase. Inflation is measured by the consumer price index, which provides an idea about the annual percentage change in the number of acquired goods and services (for a specific period) to the standard consumer. Purchasing power parities (PPPs) are the rates of currency exchange that make the purchasing power of different currencies equal by eliminating the disparities in price levels between countries. In their simplest form, PPPs are price relatives that show the proportion of the prices in national currencies of the identical good or service in different countries. In a panel data set of 36 different countries, purchasing power parity will be a useful variable for measuring cross-countries heterogeneity. PPPs are also calculated for manufactured goods groups and each of the different levels of aggregation up to and counting gross domestic product (GDP). Once we divided the household aggregate consumption and net national income data by the incorporated total population data, we obtained the per capita variables. We deflated all nominal data apart from interest rates by the consumer price index (CPI) and took the natural logarithm of all variables to construct a log-log model, which allows us to compute the elasticities. Table1 depicts the descriptive statistics.

Table 1

\section{Summary Statistics}

\begin{tabular}{|l|c|c|c|c|c|}
\hline \multirow{2}{*}{ Variables } & $(\mathbf{1})$ & $\mathbf{( 2 )}$ & $\mathbf{( 3 )}$ & $\mathbf{( 4 )}$ & $\mathbf{( 5 )}$ \\
\cline { 2 - 6 } & $\mathbf{N}$ & Mean & SD & Min & Max \\
\hline Consumption & 648 & 19972.13 & 9321.019 & 4177.261 & 44023.92 \\
Income & 648 & 32002.42 & 16611.87 & 4803.995 & 86208.93 \\
Working women & 648 & 6632.936 & 12028.33 & 71.00000 & 72944.00 \\
Young working women & 648 & 2409.993 & 4023.131 & 28.00000 & 25330.00 \\
Middle aged working women & 648 & 3122.210 & 5532.038 & 33.00000 & 33902.00 \\
Old aged working women & 648 & 1077.302 & 2210.322 & 3.000000 & 16305.00 \\
Population & 648 & 1.639301 & 0.420741 & 1.076000 & 3.930000 \\
Inflation & 648 & 2.944520 & 4.024852 & -4.478103 & 59.39572 \\
Purchasing power parity & 648 & 44.55902 & 147.2004 & 0.280000 & 898.9200 \\
\hline
\end{tabular}

Note: Consumption and income are stated in real, per capita terms. Data belongs to 36 OECD countries for the years $2000-2018$.

Source: OECD Statistics. 


\section{Methods and Estimations}

According to Keynes and Waeger (1936), consumption is a function of income, while the functional relationship between the income ' $\mathrm{I}$ ' and the consumption expenditures ' $\mathrm{C}$ ' out of a given level of income, can be expressed as below.

$$
C=f(I, Z)
$$

Or with reference to Dornbusch Fischer and Schmalensee (1993) consumption function $^{7}$ of the life cycle theory the function can be written as an equation as

$$
C=\beta_{i} I+\beta_{z} Z
$$

Here ' $C$ ' represents real per capita aggregate consumption, 'I' is the real per capita income, and ' $Z$ ' is the vector of other factors affecting aggregate consumption expenditures. The equation defines the classic relationship between consumption and income including other related determinants in vector ' $Z$ '. However, as in this research, we are particularly interested in the effect of women's work participation on aggregate consumption; our interest variable working women is a binding factor in consumption decision. Thus, we will incorporate our interest variables further in the above equation. Moreover, we will also include other indicators suggested by the previous researches as control variables. To find a long-term relationship we formulated the model using the different forms of each real variable. We further incorporated the log difference of the series to estimate the consumption elasticities of the independent variables. Thus, the full regression equation is

$$
\begin{aligned}
& \Delta \ln C_{i t}=a_{0}+\beta_{i} \Delta \ln I_{i t}+\beta_{w w} \Delta \ln W W_{i t}+\beta_{y w w} \Delta \ln Y W W_{i t}+\beta_{m w w} \Delta \ln M W W_{i t}+ \\
& +\beta_{o w w} \Delta \ln O W W_{i t}+\beta_{f r} \Delta P_{i t}+\beta_{c p i} \Delta \operatorname{Inf} f_{i t}+\beta_{p p p} \Delta P P P_{i t}+\mu
\end{aligned}
$$

$$
\begin{aligned}
& \text { where } \\
& \begin{array}{cl}
C_{i t} & \text { - the real annual aggregate household consumption of country } i \text { at time } t, \\
I_{i t} & \text { - the real annual aggregate income of country } i \text { at time } t, \\
W W_{i t} & \text { - the total number of working women of country } i \text { at time } t, \\
Y W W_{i t} & \text { - the total number of young working women of country } i \text { at time } t, \\
M W W_{i t} & \text { - the total number of mid aged working women of country } i \text { at time } t, \\
O W W_{i t} & \text { - the total number of old aged working women of country } i \text { at time } t, \\
P_{i t} & \text { - the annually estimated population of country } i \text { at time } t, \\
I n f_{i t} & \text { - the annual average inflation rate of country } i \text { at time } t, \\
P P P_{i t} & \text { - the annual purchasing power parity from country } i \text { at time } t .
\end{array}
\end{aligned}
$$

${ }^{7}$ Dornbusch and Fischer (1993) presented the model which explains the consumption patterns of individuals as a response to changes in their income. We used the simplest model form of the consumption's relationship with income and other variables. 
By estimating the value of $\beta$ 's in above equation (4) we will be able to calculate the consumption elasticities of independent variables.

$$
\varepsilon_{y w w}=\frac{d C}{d W W} \div \frac{\overline{W W}}{\bar{C}}=\beta_{w w}
$$

\subsection{Diagnostics}

Based on the above-made assumptions, the following tests have been done to propose a more appropriate estimation technique for robustness check of OLS results.

\subsubsection{Cross-sectional Dependence}

In panel data sets, especially where the time $(\mathrm{T})$ and the cross-section $(\mathrm{N})$ proportions are large; the most common issue involves is cross-sectional dependence. Cross-correlated errors may be caused by a number of reasons, such as omitted common effects, spatial effects, and interactions controlled by socioeconomic networks (Chudik and Pesaran, 2013).

Passing over cross-sectional dependence may not produce deliberate outcomes. In the presence of this issue, fixed or random effect estimations are likely to generate inconsistent and biased coefficient estimations (Sarafidis, Yamagata and Robertson, 2009). If the errors are cross-sectionally dependent conventional unit root tests will not be reliable for stationarity check. The CD test proposed by Pesaran (2020) and the LM test proposed by Pesaran and Yamagata (2008) are used to test the cross-sectional dependence of errors. The former one is used when the data entails cross-sectional characteristics is larger than the time aspect in the panel $(\mathrm{N}>\mathrm{T})$. The $\mathrm{CD}$ test is robust to the structural breaks and nonnormality of the residuals. The later one is a bias-adjusted test, which is used to solve the inconsistency problem. The CD and LM test statistic is as follows

$$
\begin{aligned}
& C D=\sqrt{\frac{2 T}{N(N-1)} F\left(\sum_{i=1}^{N-1} \sum_{j=i+1}^{N} \rho_{i j}\right) \sim N(0,1) i, j=1,2,3, \ldots \ldots, N} \\
& L M=\sqrt{\frac{2 T}{N(N-1)}} F\left(\sum_{i=1}^{N-1} \sum_{j=i+1}^{N} \rho_{i j}\right) \frac{(T-k) \rho_{i j}^{2}-E(T-k) \rho_{i j}^{2}}{\operatorname{Var}(T-k) \rho_{i j}^{2}}
\end{aligned}
$$

Here $\rho_{i j}$ is the sample estimation of the pair-wise correlation of the residual errors taken by OLS (Salmerón and Romero-Ávila, 2014).

Table 2 shows the results of the cross-sectional dependence tests. The results show the rejection of the null hypothesis, which signifies that series must be 
estimated using those methods and econometric techniques that are robust to the cross-sectional dependence issue to avoid biased outcomes.

T a ble 2

Cross-sectional Dependence Test Results

\begin{tabular}{|l|l|}
\hline & Value \\
\hline CD Test & $2.03^{*}$ \\
LM Test & 0.3945 \\
\hline
\end{tabular}

Note: $*=\mathrm{p}<10, * *=\mathrm{p}<5, * * *=\mathrm{p}<1$. The null hypothesis is no cross-sectional dependence.

Source: Own.

\subsubsection{Stationarity}

After cross-sectional dependence, we check the stationarity of all of the variables. Due to the presence of cross-sectional dependence in the errors, the CIPS panel unit root test proposed by Baltagi and Pesaran (2007) is decided to use to check the stationarity of the variables. The test is robust to cross-sectional dependence in residuals. The CIPS test uses the following augmented Dickey-Fuller regression to compute the cross-sectionally augmented ADF statistic for consumption variables.

$$
\Delta C_{i, t}=a_{i}+b_{i} C_{i, t-1}+c_{i} \bar{C}_{t-1}+d_{i} \Delta C_{t}+\varepsilon_{i t}
$$

Here $\bar{y}_{t}=\frac{1}{N} \sum_{i=1}^{N} C_{i, t}$ and $\Delta y_{t}=\frac{1}{N} \sum_{i=1}^{N} \Delta C_{i, t}$

and

$$
\mathrm{CIPS}=\frac{1}{N} \sum_{i=1}^{N} C A D F_{i}
$$

Similarly, the CADF will be calculated for all other series used in empirical research.

T a b l e 3

\section{CIPS Unit Root Test Results}

\begin{tabular}{|l|c|c|}
\hline \multirow{2}{*}{} & \multicolumn{2}{|c|}{ CIPS } \\
\cline { 2 - 3 } & Intercept & Intercept Trend \\
\hline Consumption & -1.834 & -2.059 \\
Income & -1.911 & -2.528 \\
Working Women & -1.530 & -1.592 \\
FertilityRate & -1.731 & -2.641 \\
CPI & -2.045 & -2.839 \\
PPP & -1.509 & -1.539 \\
\hline
\end{tabular}

Note: $*=\mathrm{p}<10, * *=\mathrm{p}<5, * * *=\mathrm{p}<1$. For the CIPS test the null hypothesis is non-stationarity. Source: Own. 
The results obtained from the CIPS unit root test are given in Table 3. The values calculated for all variables indicate the acceptance of the null hypothesis of a unit root demonstrating all the series non-stationary in level form.

\subsubsection{Cointegration}

The results of the unit root test indicate that all series are stationary at level with the order I (1). If there is a linear arrangement of the variables, cointegration can facilitate to use of non-stationary variables at levels with no spurious relationship among them (Hubrich et al., 2001). To find out whether these series are cointegrated, Durbin-Hausman test proposed by Westerlund (2008), which takes crosssectional dependence into account. The test creates two test statistics, namely panel test (DHp) and group test (DHL). The panel test (DHp) assumes that the autoregressive constraints are similar for all the cross-sections. The group test (DHg) permits the autoregressive parameter to be different across cross-sections. In both of the tests, rejection of the null hypothesis concludes that cointegration exists.

The DHg and the DHp figures presented in Table 4 reject the null hypothesis of no cointegration. Thus, it is concluded that the variables are cointegrated. The results advocate that consumption expenditures have a long-term relationship with working women and other variables.

T a b l e 4

Durbin-Hausman Cointegration Test Results

\begin{tabular}{|l|l|}
\hline & Value \\
\hline DHg & $-1.81 * * *$ \\
DHp & $-4.02 * *$ \\
\hline
\end{tabular}

Note: $*=\mathrm{p}<10, * *=\mathrm{p}<5, * * *=\mathrm{p}<1$. The null hypothesis is no cointegration.

Source: Own.

Summering up the analytical tests, the most important issue found was crosssectional dependence in errors. Besides, when dealing with large cross-sections series heteroscedasticity issue frequently arises. Therefore, there should be a specific regression with robust standard errors. Previous researches also reveal that consumption expenditures series can be endogenous in a number of models (Campbell and Cocco, 2007). The instrumental variable techniques are best to get robust estimations and to solve all these problems altogether in one estimation. Thus, it is decided to employ the generalized method of moments (GMM) and two-stage least-squares (2SLS). Driscoll and Kraay (1998) standard errors help out with the issue of cross-sectional dependence as well as heteroscedasticity and serial correlation. Thus, 2SLS and GMM estimations are further measured with Driscoll and Kraay (1998) and cluster standard errors. 
Following Campbell and Cocco (2007), instrument variables are used for consumption and income series. The instrument variables include those variables which affect these variables together as well as in parallel. These include lagged per capita consumption expenditures, lagged per capita income, inflation, and lagged per capita GDP. After fitting the auxiliary regression Hausman test proposed by Wooldridge (2002) is employed to check for the random or fixed effect. The insignificant test statistic for all models indicated the presence of fixed effects. Thus equation (3) is estimated by fixed-effect models with the generalized method of moments (GMM) and two-stage least-squares (2SLS) techniques with Driscoll and Kraay (1998) cluster standard errors.

\subsection{Causality}

The above diagnostics do not have information on the causal relationship between the variables used in the model. To complement the empirical analysis, the Granger causality test proposed by Dumitrescu and Hurlin (2012) is employed to check the causality between the variables. The test is robust to the cross-sectional dependence and involves a separate Granger non-causality calculation for all cross-sections. The Dumitrescu-Hurlin panel causality test equation for consumption and working women variable is as follows

$$
C_{i, t}=\alpha_{i}+\sum_{i=k}^{K} \beta_{i} C_{i, t-k}+\sum_{i=k}^{K} \gamma_{i} W W_{i, t-k}+\varepsilon_{i, t}
$$

Here ' $\mathrm{k}$ ' is the lag order.

The Dumitrescu-Hurlin panel non-causality test presumes the nonexistence of casual relationships for all the cross-sections in the panel. The null hypothesis is

$$
H_{0}=\gamma_{i 1}=\gamma_{i 2}=\ldots=\gamma_{i k}=0 \quad \forall_{i}=1,2, \ldots, N
$$

The test builds the Wald statistic ' $\mathrm{W}$ ' to check the null hypothesis

$$
\bar{W}=\frac{1}{N} \sum_{1}^{N} W_{i}
$$

It is assumed that the Wald statistics are independently and identically distributed across individuals. The consistent $\bar{Z}$ and $\tilde{Z}$ Wald statistics can be calculated as

$$
\bar{Z}=\sqrt{\frac{N}{2 K}}(\bar{W}-K)
$$

and

$$
\tilde{Z}=\sqrt{\frac{N}{2 K}\left(\frac{T-3 K-5}{T-2 K-3}\right)\left(\frac{T-3 K-3}{T-3 K-1}\right)}(\bar{W}-K)
$$


Here ' $\mathrm{T}$ ' represents the number of time periods, ' $\mathrm{N}$ ' represents the number of cross-sections, and ' $\mathrm{K}$ ' represents the number of lags. If the computed $\bar{Z}$ and $\tilde{Z}$ Wald statistics are bigger than the critical values the null hypothesis of noncausality is rejected, which in turn represents the causal relationship between variables.

Table 5 represents the results of Dumitrescu-Hurlin panel causality test. These results suggest the existence of the bidirectional causal relationship between the pairs of consumption with income and consumption with working women. The results further illustrate bidirectional causalities between all other variables except income-inflation and population-inflation. The results suggest unidirectional causalities from income to inflation and from inflation to population.

Table 5

\section{Dumitrescu-Hurlin Panel Causality Test Results}

\begin{tabular}{|c|c|c|c|}
\hline Direction of Causality & $\overline{\boldsymbol{Z}}$ & $\widetilde{\boldsymbol{Z}}$ & Result \\
\hline $\begin{array}{l}\text { Income } \longrightarrow \text { Consumption } \\
\text { Consumption } \longrightarrow \text { Income }\end{array}$ & $\begin{array}{l}9.3480^{* * * *} \\
7.2045^{* * *}\end{array}$ & $\begin{array}{l}6.8275 * * \\
4.9357 * * *\end{array}$ & Bidirectional Causality \\
\hline $\begin{array}{l}\text { Working Women } \longrightarrow \text { Consumption } \\
\text { Consumption } \longrightarrow \text { Working Women }\end{array}$ & $\begin{array}{l}4.3593 * * * \\
9.3958 * *\end{array}$ & $\begin{array}{l}3.2947 * * * \\
6.3837 * * *\end{array}$ & Bidirectional Causality \\
\hline $\begin{array}{l}\text { Fertility rate } \longrightarrow \text { Consumption } \\
\text { Consumption } \longrightarrow \text { Fertility rate }\end{array}$ & $\begin{array}{l}10.9339 * * * \\
22.8521 * * *\end{array}$ & $\begin{array}{c}8.5858 * * \\
19.5535^{* * *}\end{array}$ & Bidirectional Causality \\
\hline $\begin{array}{l}\text { Inflation } \longrightarrow \text { Consumption } \\
\text { Consumption } \longrightarrow \text { Inflation }\end{array}$ & $\begin{array}{r}19.3927 * * * \\
4.8395 * * * \\
\end{array}$ & $\begin{array}{r}13.1194 * * * \\
2.8395 * * * \\
\end{array}$ & Bidirectional Causality \\
\hline $\begin{array}{l}\text { Working Women } \longrightarrow \text { Income } \\
\text { Income } \longrightarrow \text { Working Women }\end{array}$ & $\begin{array}{l}16.9375 * * \\
27.8325 * * *\end{array}$ & $\begin{array}{l}11.8885^{* * * *} \\
21.9293^{* * *}\end{array}$ & Bidirectional Causality \\
\hline $\begin{array}{l}\text { Population } \longrightarrow \text { Income } \\
\text { Income } \longrightarrow \text { Population }\end{array}$ & $\begin{array}{l}13.8375 * * * \\
15.4485 * * *\end{array}$ & $\begin{array}{l}10.9272 * * * \\
10.9308 * * *\end{array}$ & Bidirectional Causality \\
\hline $\begin{array}{l}\text { Inflation } \longrightarrow \text { Income } \\
\text { Income } \longrightarrow \text { Inflation }\end{array}$ & $\begin{array}{c}16.1358 * * * \\
2.3397 * * \\
\end{array}$ & $\begin{array}{l}12.2224 * * * \\
1.3857\end{array}$ & $\begin{array}{l}\text { Unidirectional Causality } \\
\text { (Inflation to Income) }\end{array}$ \\
\hline $\begin{array}{l}\text { Population } \longrightarrow \text { Working Women } \\
\text { Working Women } \longrightarrow \text { Population }\end{array}$ & $\begin{array}{l}7.3445 * * * \\
9.9785^{* * * *}\end{array}$ & $\begin{array}{l}4.8575 * * \\
6.1454 * * *\end{array}$ & Bidirectional Causality \\
\hline $\begin{array}{l}\text { Inflation } \longrightarrow \text { Working Women } \\
\text { Working Women } \longrightarrow \text { Inflation }\end{array}$ & $\begin{array}{l}7.0254 * * * \\
9.2344 * * *\end{array}$ & $\begin{array}{l}5.0035 * * \\
6.9274 * * *\end{array}$ & Bidirectional Causality \\
\hline $\begin{array}{l}\text { Inflation } \longrightarrow \text { Population } \\
\text { Population } \longrightarrow \text { Inflation }\end{array}$ & $\begin{array}{l}1.0448 \\
2.7849 * * *\end{array}$ & $\begin{array}{l}1.3554 \\
1.9987\end{array}$ & $\begin{array}{l}\text { Unidirectional Causality } \\
\text { (Population to Inflation) }\end{array}$ \\
\hline
\end{tabular}

Note: $*=\mathrm{p}<10, * *=\mathrm{p}<5, * * *=\mathrm{p}<1$. Lag orders have been selected according to the Akaike Information Criteria.

Source: Own.

\subsection{Regression Results}

Table 6 and Table 7 summarizes the results obtained from the generalized method of moments (GMM) and two-stage least-squares (2SLS) techniques with Driscoll and Kraay (1998) cluster standard errors. Estimates of the basic model with working women variable are given in columns (1) written as Model 1, while columns (2) to (4) reports estimated results of the estimations with three specifications of different age groups; young, middle, and old aged working women series. 
In Model 1, the result shows a positive and statistically significant relationship between the number of working women and consumption. The estimated value of the elasticity coefficient of working women indicates that if all other variables are constant, a $1 \%$ increase in the number of working women will cause a $0.17 \%$ increase in per capita household consumption expenditures approximately. Thus, we can conclude that the higher the number of working women, the greater the increase in per capita household consumption expenditures.

The results of the other three models (Model 2 to Model 4) also show a positive and statistically significant relationship between consumption and each of the specifications of working women. The estimated values of the elasticity coefficients of young, middle, and old-aged women are $0.18,0.23$, and 0.08 respectively. The highest coefficient value of middle-aged working women variable shows that compared to young and old-aged working women, middle-age working women have a strong effect on per capita household consumption expenditures. Following middle aged working women, young working women have a bigger value of elasticity coefficient than old aged working women, which indicates that compared to old aged women, young working women are more likely to affect per capita household consumption expenditures.

T a b l e 6

GMM Regression Estimation Results

\begin{tabular}{|c|c|c|c|c|}
\hline & Model 1 & Model 2 & Model 3 & Model 4 \\
\hline \multicolumn{5}{|l|}{ Interest Variables } \\
\hline Working Women & $\begin{array}{l}0.1773 * * * \\
(0.0808)\end{array}$ & & & \\
\hline $\begin{array}{l}\text { Young Aged Working } \\
\text { Women }\end{array}$ & & $\begin{array}{l}0.1893 * * * \\
(0.0772)\end{array}$ & & \\
\hline $\begin{array}{l}\text { Middle Aged Working } \\
\text { Women }\end{array}$ & & & $\begin{array}{l}0.2301 * * * \\
(0.0873)\end{array}$ & \\
\hline $\begin{array}{l}\text { Old Aged Working } \\
\text { Women }\end{array}$ & & & & $\begin{array}{l}0.0830^{* * * *} \\
(0.0661) \\
\end{array}$ \\
\hline \multicolumn{5}{|l|}{ Control Variables } \\
\hline Income & $\begin{array}{l}0.5992 * * * \\
(0.0298)\end{array}$ & $\begin{array}{l}0.6189 \text { *** } \\
(0.0227)\end{array}$ & $\begin{array}{l}0.6007 * * * \\
(0.0182)\end{array}$ & $\begin{array}{l}0.5859 * * * \\
(0.0119)\end{array}$ \\
\hline Population & $\begin{array}{l}0.0502 * * * \\
(0.0095)\end{array}$ & $\begin{array}{c}0.0749 \\
(0.0089) \\
\end{array}$ & $\begin{array}{l}0.0304 * * * \\
(0.0104)\end{array}$ & $\begin{array}{l}0.0532 * * * \\
(0.0088)\end{array}$ \\
\hline $\begin{array}{l}\text { Inflation } \\
\text { Purchasing power } \\
\text { parity }\end{array}$ & $\begin{array}{l}-0.0032 * * * \\
(0.0003) \\
-0.0006^{* * *} \\
(0.0000) \\
\end{array}$ & $\begin{array}{l}-0.0024 * * * \\
(0.0002) \\
-0.0006 * * * \\
(0.0000) \\
\end{array}$ & $\begin{array}{c}-0.0061 * * * \\
(0.0013) \\
-0.0007 * * * \\
(0.0000) \\
\end{array}$ & $\begin{array}{l}0.0029 * * * \\
(0.0007) \\
-0.0006 * * * \\
(0.0000) \\
\end{array}$ \\
\hline $\begin{array}{l}\text { Observations } \\
\text { Centered/Uncenterd } \mathrm{R}^{2} \\
\text { Residual SS }\end{array}$ & $\begin{array}{r}648 \\
0.6013 \\
13.8364 \\
\end{array}$ & $\begin{array}{l}648 \\
0.6029 \\
10.6374 \\
\end{array}$ & $\begin{array}{r}648 \\
0.4878 \\
14.8573 \\
\end{array}$ & $\begin{array}{l}648 \\
0.6770 \\
9.4858 \\
\end{array}$ \\
\hline
\end{tabular}

Note: $*=\mathrm{p}<10, * *=\mathrm{p}<5, * * *=\mathrm{p}<1$.

Source: Own. 
After exploration of results concerning the control variables, we can see that income and population variables have positive and statistically significant coefficients in all of the four models of Table 6 . Inflation and purchasing power parity variables have negative and statistically significant coefficients in all of the specifications. The coefficients of the income variable have the largest estimated values in all of the four models. This shows that most of the dynamics in consumption expenditures are explained by income. Other control variables due to their small coefficient value do not bring much change in consumption expenditures. These elasticity coefficients are showing the percentage changes in consumption concerning the change in each of these control variables.

Table 7 presents the estimated results of 2SLS regressions. As in Table 6, the results are presented in four estimated models (Model 1 to Model 4). After a close look at the statistical significance of the estimated coefficients, it is clear, that the results of 2SLS estimations differ little from the results of GMM estimations. Whereas compared to GMM estimations the values of the estimated coefficients of 2SLS estimations are small in magnitude. These results also show a similar direction of the relationship between consumption expenditures and all independent variables.

T a ble 7

2SLS Regression Estimation Results

\begin{tabular}{|c|c|c|c|c|}
\hline & Model 1 & Model 2 & Model 3 & Model 4 \\
\hline \multicolumn{5}{|l|}{ Interest Variables } \\
\hline Working Women & $\begin{array}{l}0.1729 * * * \\
(0.0394)\end{array}$ & & & \\
\hline $\begin{array}{l}\text { Young Aged Working } \\
\text { Women }\end{array}$ & & $\begin{array}{l}0.1629 * * * \\
(0.0944)\end{array}$ & & \\
\hline $\begin{array}{l}\text { Middle Aged Working } \\
\text { Women }\end{array}$ & & & $\begin{array}{l}0.2104 * * * \\
(0.0934)\end{array}$ & \\
\hline $\begin{array}{l}\text { Old Aged Working } \\
\text { Women }\end{array}$ & & & & $\begin{array}{l}0.0729 * * * \\
(0.0284)\end{array}$ \\
\hline \multicolumn{5}{|l|}{ Control Variables } \\
\hline Income & $\begin{array}{l}0.5330 * * * \\
(0.0133)\end{array}$ & $\begin{array}{l}0.6092 * * * \\
(0.0210)\end{array}$ & $\begin{array}{l}0.5739 * * * \\
(0.0372)\end{array}$ & $\begin{array}{l}0.5502 * * * \\
(0.0190)\end{array}$ \\
\hline Population & $\begin{array}{l}0.0420 * * \\
(0.0092)\end{array}$ & $\begin{array}{c}0.0849 \\
(0.0096)\end{array}$ & $\begin{array}{l}0.0241 * * * \\
(0.0193)\end{array}$ & $\begin{array}{l}-0.0435 * * * \\
(0.0135)\end{array}$ \\
\hline $\begin{array}{l}\text { Inflation } \\
\text { Purchasing Power } \\
\text { Parity }\end{array}$ & $\begin{array}{l}-0.0039^{* * *} \\
(0.0007) \\
-0.0006^{* * *} \\
(0.0000) \\
\end{array}$ & $\begin{array}{l}-0.0028^{* *} \\
(0.0010) \\
-0.0006^{* * *} \\
(0.0000) \\
\end{array}$ & $\begin{array}{l}-0.0057 * * * \\
(0.0019) \\
-0.0006 * * * \\
(0.0000) \\
\end{array}$ & $\begin{array}{l}0.0021^{* * *} \\
(0.0006) \\
-0.0006^{* *} \\
(0.0000) \\
\end{array}$ \\
\hline $\begin{array}{l}\text { Observations } \\
\text { Centered/ Uncenterd } \mathrm{R}^{2} \\
\text { Residual SS }\end{array}$ & $\begin{array}{r}648 \\
0.5909 \\
10.3855\end{array}$ & $\begin{array}{l}648 \\
0.6082 \\
10.5957\end{array}$ & $\begin{array}{l}648 \\
0.5012 \\
13.5495\end{array}$ & $\begin{array}{l}648 \\
0.6734 \\
9.3 \mathrm{I} 53\end{array}$ \\
\hline
\end{tabular}

Note: $*=\mathrm{p}<10, * *=\mathrm{p}<5, * * *=\mathrm{p}<1$.

Source: Own. 
The estimated value of the elasticity coefficient of working women in Model 1 indicates that if all other variables are constant, a $1 \%$ increase in the number of working women will cause a $0.17 \%$ increase in per capita household consumption expenditures approximately. The estimated values of the elasticity coefficients of young, middle, and old aged are $0.16,0.21$, and 0.07 respectively. The results show a small but positive effect of the number of working women on per capita household consumption expenditures. The effect of middle-aged (35-54 years old) working women is higher than young and old aged women.

Furthermore, the robustness check of the models presented in Table 6 and Table 7 was performed. The results from robust regressions are quite similar tothe original estimation results, which increases the reliability of the original results.

\section{Discussion and Policy Implications}

Our research supports the existing literature showing that the spending behavior of working women differs from others. The descriptive analysis of the relationship between the number of working women and consumption expenditures in the sample shows that the increase in the number of working women causes a significant increase in per capita household consumption expenditures through their high spending patterns. The descriptive analysis also indicates that middleaged working women in the sample were likely to affect the per capita consumption expenditures more. In general, young working women are acknowledged as compulsive buyers. The high bargaining power from their earnings should cause the highest elasticity coefficient of consumption. The specific reasons for these findings could be seen in a micro-level analysis of the individual country.

The study on a macro level signifies an extensive understanding of the phenomenon of women's spending behavior and its positive impact on the economy. Along with the theoretical discussion, the detailed empirical analysis provides evidence of the observed facts. The findings prove the importance of working women for gross domestic consumption. Thus, this study is practical for both policymakers and researchers. On account of many developing economies, females' freedom and support for an equal work environment need more extensive research. Our findings suggest that women's contribution to work outside of the house brings a positive change in economic activity. Thus, there should be more female work-friendly policies to support economic growth, especially for the developing countries where female participation in work outside of the home is relatively low. Engaging women in work can boost economic growth through shifts in consumption levels. The results for different age categories suggest that there should be separate implementation strategies for women of different age groups. 
This is to encourage females' spending; hence companies should make separate marketing strategies for young, middle-aged, and older working women. The current sample includes the aggregated data for measuring aggregate effects, which limits the purpose of the findings to detailed aspects of households. This concept can be further examined on the micro-level. This understanding would be constructive for future enhancements in gross consumption and economic development.

\section{Conclusion}

With the rapid economic growth and social development, the proportion of working women has increased enormously. This change improved their bargaining power and spending patterns due to their income along with other factors. Using a panel data set ranging from 2000 - 2018 for 36 OECD countries, this paper empirically examined the relationship between working women and consumption expenditures.

We employed the Granger causality test introduced by Dumitrescu and Hurlin (2012) and found bidirectional causality between consumption expenditures and working women with all other independent variables. The basic model was then estimated using 2SLS and GMM techniques with cluster standard errors by controlling the problem of cross-sectional dependence and endogeneity. The results showed that changes in the number of working women have a significant and positive effect on per capita household consumption expenditures. These results are similar to the findings obtained in Gupta and Kaur's (2017) study, which confirms the differences between the spending patterns of working and nonworking women in a micro-data analysis. The results also support two of the hypotheses, $\mathrm{H} 1$ and $\mathrm{H} 3$, indicating that working women positively affect consumption expenditures.

These findings further illustrate that age plays a significant role in working women's spending behavior dynamics. Compared to young and older working women, middle-aged working women have a higher influence on total household expenditures. These results present a long-term positive relationship between the number of working women and per capita consumption expenditures. In the long term, with the increase in the number of working women, per capita household consumption expenditures will increase. Regardless of the way that young working women are considered as more influential buyers, the working women in the middle-age category are more likely to affect per capita consumption expenditures. This may be explained by high-income level and family expenses. Due to a more extensive analysis, the results from this research integrate the Manchanda (2012) findings by covering broad aspects. Our research contributes to the literature 
based on three important aspects; firstly, we build the conceptual framework based on numerous channels and provide valid reasons to verify our arguments depending on the relationship between working women and consumption expenditures. Secondly, the study categories for working women are divided into three separate age groups and are analyzed depending on the concept for each group separately. Previous studies on the subject did not provide such details. Thirdly, there is no previous study available on this topic using secondary data. Using aggregate data for several industrialized economies makes these results more useful for policy implications on a large scale. ${ }^{8}$ Also, the use of primary data involves extra human error, thus providing less authentic results. This research offers a major contribution to literature and encourages others to pursue further investigation on this topic.

\section{References}

ADDESSI, W. (2018): Population Age Structure and Consumption Expenditure Composition: Evidence from European Countries. Economics Letters, 168, No. 7, pp. 18 - 20. Available at: <https://doi.org/10.1016/j.econlet.2018.03.033>.

ANDERSON, S. - ESWARAN, M. (2009): What Determines Female Autonomy? Evidence from Bangladesh. Journal of Development Economics, 90, No. 2, pp. 179 - 191. Available at: <https://doi.org/10.1016/j.jdeveco.2008.10.004>.

BALTAGI, B. H. - PESARAN, M. H. (2007): Heterogeneity and Cross Section Dependence in Panel Data Models: Theory and Applications Introduction. Journal of Applied Econometrics, 22, No. 2, pp. 229 - 232. Available at: 〈https://doi.org/10.1002/jae.955>.

BATTISTIN, E. - PADULA, M. (2010): Survey Instruments and the Reports of Consumption Expenditures: Evidence from the Consumer Expenditure Surveys. [CEPR Discussion Papers.] Available at: <https://www.tse-fr.eu/sites/default/files/medias/stories/SEMIN_09_10/ECONOMETRIE/battistin.pdf>.

BEBLO, M. - BENINGER, D. (2012): Do Husbands and Wives Pool Their Incomes? Experimental Evidence. Working Papers of BETA, 234, No. 6, pp. 120 - 141. Available at: <https://doi.org10.3848/iif.2014.337.3928>.

BHUPAL, G. - SAM, A. G. (2014): Female Income and Expenditure on Children: Impact of the National Rural Employment Guarantee Scheme in India. Applied Econometrics and International Development, 14, No. 2, pp. 175 - 192.

BODUR, F. B. - AVCI, G. M. (2016): Household Expenditure Patterns: Evidence from Workingcouple Households in Turkey. International Review of Economics and Management, 3, No. 2, pp. 85 - 108. Available at: 〈https://doi.org10.18825/irem.23503>.

BONKE, J. - BROWNING, M. (2010): The Allocation of Expenditures within the Household: A New Survey. Fiscal Studies, 30, No. 3 - 4, pp. 461 - 481. Available at: <https://doi.org10.1111/j.1475-5890.2009.00104.x>.

BROWNING, M. - CHIAPPORI, P. (1998): Efficient Intra-household Allocations: A General Characterization and Empirical Tests. Econometrica, 66, No. 6, pp. 1241 - 1278.

\footnotetext{
${ }^{8}$ Previous research mostly debates on working women's compulsive buying behavior and its impact on their spending patterns. Whereas this study includes the theoretical discussion on several other aspects affecting working women's buying behavior and presents an extensive empirical analysis on aggregated data.
} 
BROWNING, M. - PIERRE-ANDRE, C. - ARTHUR, L. (2013): Estimating Consumption Economies of Scale, Adult Equivalence Scales, and Household Bargaining Power. Review of Economic Studies, 80, No. 4, pp. 1267 - 1303.

BUVINIC, M. - FURST-NICHOLS, R. (2014): Promoting Women's Economic Empowerment: What Works? Policy Research Working Paper, 31, No. 59 - 101, pp. 1 - 47.

CAMPBELL, J. Y. - COCCO, J. F. (2007): How Do House Prices Affect Consumption? Evidence from Micro Data. Journal of monetary Economics, 54, No. 3, pp. 591 - 621. Available at: <https://doi.org10.1016/j.jmoneco.2005.10.016>.

CHATTERJEE, S. (2009): The Peopling of Macroeconomics: Microeconomics of Aggregate Consumer Expenditures. Business Review, Federal Reserve Bank of Philadelphia. Available at: $\langle$ http://citeseerx.ist.psu.edu/viewdoc/download?doi=10.1.1.421.1144\&rep=rep1\&type=pdf〉.

CHEN, Z. - WOOLLEY, F. (2001): A Cournot-nash Model of Family Decision Making. Economic Journal, 111, No. 474, pp. 722 - 748. Available at: <https://doi.org10.2307/798410〉.

CHUDIK, A. - PESARAN, M. H. (2013): Large Panel Data Models with Cross-sectional Dependence: A Survey. [CAFE Research Paper, No. 13.15.] Available at: <https://doi.org10.2139/ssrn.2316333>.

CUPAK, A. - PORKRIVCAK, J. - RIZOV, M. (2016): Demand for Food Away from Home in Slovakia. Finance auver-Czech Journal of Economic and Finance, 66, No. 4, pp. 354 - 369.

CUSHING, M. J. (1991): Under-sensitivity and Under-volatility in Aggregate Consumption Expenditures. Journal of Macroeconomics, 13, No. 1, pp. 1 - 24. Available at: <https://doi.org10.1016/0164-0704(91)90028-S>.

D'ASPREMONT, C. - FERREIRA, R. D. S. (2019): Enlarging the Collective Model of Household Behavior: A Revealed Preference Analysis. Economic Theory, 68, No. 1, pp. 1 - 19. Available at: 〈https://doi.org10.1007/s00199-018-1110-3>.

De WEESE, G. A. I. L. - NORTON, M. J. (1991): Impact of Married Women's Employment on Individual Household Member Expenditures for Clothing. Journal of Consumer Affairs, 25, No. 2, pp. 235 - 257. Available at: 〈https://doi.org10.1111/j.1745-6606.1991.tb00004.x〉.

DELGADO, M. A. - MILES, D. (1997): Household Characteristics and Consumption Behaviour: A Nonparametric Approach. Empirical Economics, 22, No. 3, pp. 409 - 429. Available at: <https://doi.org10.1007/BF01208831>.

DORNBUSCH, R. - FISCHER, S. - SCHMALENSEE, R. (1993): Economía/stanley fischer, rudiger dornbusch, richard schmalensee traducciónluis toharia, esther rabasco. Madrid: McGraw-Hill. ISBN 10:8476156839.

DRISCOLL, J. C. - KRAAY, A. C. (1998): Consistent Covariance Matrix Estimation with Spatially Dependent Panel Data. Review of Economics and Statistics, 80, No. 4, pp. $549-560$. Available at: 〈https://doi.org/10.1162/003465398557825>.

DUMITRESCU, E. I. - HURLIN, C. (2012): Testing for Granger Non-causality in Heterogeneous Panels. Economic Modelling, 29, No. 4, pp. 1450 - 1460. Available at: <https://doi.org/10.1016/j.econmod.2012.02.014>.

FISHER, J. D. - JOHNSON, D. S. - SMEEDING, T. M. - THOMPSON, J. P. (2020): Estimating the Marginal Propensity to Consume Using the Distributions of Income, Consumption, and Wealth. Journal of Macroeconomics, 65, No. 3, pp. 103 - 218. Available at: <https://doi.org/10.1016/j.jmacro.2020.103218>.

FOSTER, A. C. -MAMMEN, S. (1992): Impact of Wife's Employment on Service Expenditures. Journal of Consumer Studies \& Home Economics, 16, No. 1, pp. 9 - 18. Available at: <https://doi.org/10.1111/j.1470-6431.1992.tb00495.x>.

GERSTBERGER, C. - YANEVA, D. (2013): Analysis of EU-27 Household Final Consumption Expenditure: Baltic Countries and Greece Still Suffering Most from the Economic and Financial Crisis. Eurostat Statistics in Focus, No. 2/2013. Available at: 〈http://www.bit.ly/1n2s521>.

GUPTA, D. B. - KAUR, T. P. (2017): Spending Behaviour, Preferences and Pattern of Working and Non-Working Women: A Comparative Analysis with Special Reference to Punjab State. Asian Journal of Research in Business Economics and Management, 7, No. 8, pp. $126-141$. Available at: 〈https://doi.org/10.5958/2249-7307.2017.00135.9>. 
HANDA, S. - PETERMAN, A. - DAVIS, B. - STAMPINI, M. (2009): Opening Up Pandora's Box: The Effect of Gender Targeting and Conditionality on Household Spending Behavior in Mexico's Progresa Program. World Development, 37, No. 6, pp. 1129 - 1142. Available at: <https://doi.org/10.1016/j.worlddev.2008.10.005>.

HANDAYANI, L. - HANDAYANI, D. (2019): Working Women and Household Expenditures on Food Away from Home in Indonesia. Pertanika Journal of Social Sciences \& Humanities, 27, No. 2, pp. $62-69$.

HANSON, S. L. - OOMS, T. (1991): The Economic Costs and Rewards of Two-earner, Twoparent Families. Journal of Marriage and the Family, 53, No. 3, pp. 622 - 634. Available at: <https://doi.org/10.2307/352738>.

HODDINOTT, J. - HADDAD, L. (1995): Female Income Share Influence Household Expenditure? Evidence from Cote d'Ivoire. Oxford Bulletin of Economics and Statistics, 57, No. 1, pp. 77 - 96. Available at: 〈https://doi.org/10.1111/j.1468-0084.1995.tb00028.x〉.

HOPKINS, J. - LEVIN, C. - HADDAD, L. (1994): Women's Income and Household Expenditure Patterns: Gender or Flow? Evidence from Nigeria. American Journal of Agricultural Economics, 76, No. 5, pp. $1219-1225$.

HUBRICH, K. - HELMUT, L. - LUTKEPOHL, H. - SAIKKONEN, P. (2001): A Review of System Cointegration Tests. Econometric Reviews, 20, No. 3, pp. 247 - 318. Available at: <https://doi.org/10.1081/ETC-100104936>.

IBRAHIM, M. H. - HABIBULLAH, M. S. (2010): Stock Market and Aggregate Consumption Asymmetry: Evidence from Malaysia. Studies in Economics \& Finance, 27, No. 1, pp. 19 - 29. Available at: 〈https://doi.org/10.1108/10867371011022957>.

IPSOS UPDATE - September 2018. Available at: <https://www.ipsos.com/en/ipsos-update-september-2018>.

JOIREMAN, J. - KEES, J. - SPROTT, D. (2010): Concern with Immediate Consequences Magnifies the Impact of Compulsive Buying Tendencies on College Students' Credit Card Debt. Journal of Consumer Affairs, 44, No. 1, pp. 155 - 178. Available at: <https://doi.org/10.1111/j.1745-6606.2010.01161.x>.

JOJI, N. A. - RAVEENDRAN, P. T. (2008): Compulsive Buying Behavior in Indian Consumers and Its Impact on Credit Default - An Emerging Paradigm. Indian Institute of Management Kozhikode. Available at: 〈http://dspace.iimk.ac.in/bitstream/2259/329/1/545-562.pdf>.

JUN, W. - JAMIL, I. - MUGHAL, B. - WAHEED, J. - HUSSAIN, H. (2020): Does Working Women's Causes Innovation: An Untouched Reality?. E + M Ekonomie a Management, 23, No. 4, pp. 102 - 119. Available at: 〈https://doi.org/10.15240/tul/001/2020-4-007〉.

KENG, S. H. - LIN, Ch.-H. (2005): Wives' Value of Time and Food Consumed Away from Home in Taiwan. Asian Economic Journal, 19, No. 3, pp. 319 - 334. Available at: <https://doi.org/10.1111/j.1467-8381.2005.00215.x>.

KEYNES, J. M. - WAEGER, F. (1936): Allgemeine Theorie der Beschäftigung, des Zinses und des Geldes. Berlin: Duncker \& Humblot.

KILLEWALD, A. (2011): Opting Out and Buying Out: Wives' Earnings and Housework Time. Journal of Marriage and Family, 73, No. 2, pp. 459 - 471. Available at: <https://doi.org/10.1111/j.1741-3737.2010.00818.x>.

KOOLWAL, G. - RAY, R. (2002): Estimating the Endogenously Determined Intrahousehold Balance of Power and Its Impact on Expenditure Pattern: Evidence from Nepal. [Policy Research Working Paper Series.] Available at: <https://ssrn.com/abstract=636097>.

KORNRICH, S. - ROBERTS, A. (2018): Household Income, Women's Earnings, and Spending on Household Services, 1980 - 2010. Journal of Marriage \& Family, 80, No. 1, pp. 150 - 165. Available at: 〈https://doi.org/10.1111/jomf.12450>.

KUKAR-KINNEY, M. - RIDGWAY, N. M. - MONROE, K. B. (2009): The Relationship between Consumers' Tendencies to Buy Compulsively and Their Motivations to Shop and Buy on the Internet. Journal of Retailing, 85, No. 3, pp. 298 - 307. Available at: <https://doi.org/10.1016/j.jretai.2009.05.002>. 
LAHIRI, K. - MONOKROUSSOS, G. - ZHAO, Y. (2015): Forecasting Consumption: The Role of Consumer Confidence in Real Time with Many Predictors. Journal of Applied Econometrics, 31, No. 7, pp. 1254 - 1275. Available at: 〈https://doi.org/10.1002/jae.2494〉.

LANCASTER, G. - PUSHKAR, M. - RANJAN, R. (2008): Household Expenditure Patterns and Gender Bias: Evidence from Selected Indian States. Oxford Development Studies, 36, No. 2, pp. 133 - 157. Available at: 〈https://doi.org/10.1080/13600810802037803〉.

LEE, J. - POCOCK, M. L. (2007): Intra Household Allocation of Financial Resources: Evidence from South Korean Individual Bank Accounts. Review of Economics of the Household, 5, No. 1, pp. 41 - 58. Available at: 〈https://doi.org/10.1007/s11150-007-9004-3〉.

LEE, S. - JINKOOK, L. - YUNHEE, C. (2011): What is the Cost of Married Women's Paid Work? [RAND Working Paper Series, No. WR-830.] Available at: <http://dx.doi.org/10.2139/ssrn.1749698>.

LEE, S. - JINKOOK, L. - YUNHEE, C. (2014): Is Dual Income Costly for Married Couples? An Analysis of Household Expenditures. Journal of Family and Economic Issues, 35, No. 2, pp. 161 - 177. Available at: 〈https://doi.org/10.1007/s10834-013-9364-1〉.

MANASSEH, C. O. - ABADA, F. C. - OGBUABOR, J. E. - ONWUMERE, J. U. J. - URAMA, C. E. - OKORO, O. E. (2018): The Effects of Interest and Inflation Rates on Consumption Expenditure: Application of Consumer Spending Model. International Journal of Economics and Financial Issues, 8, No. 4, pp. $32-38$.

MANCHANDA, R. (2012): A Comparative Study of Compulsive Buying Behaviour between Working and Non-Working Women. Pragyaan; Journal of Management, 27, No. 28, pp. 1 - 9.

MANCHANDA, R. (2015): Materialism and Compulsive Buying: An Exploration of Indian Youth. International Journal of Business Quantitative Economics and Applied Management Research, 2, No. 4, pp. $28-40$.

MANRIQUE, J. - JENSEN, H. H. (1998): Working Women and Expenditures on Food Awayfrom-home and at-home in Spain. Journal of Agricultural Economics, 49, No. 3, pp. 321 - 333. Available at: 〈https://doi.org/10.1111/j.1477-9552.1998.tb01275.x>.

MEHRA, Y. P. (2001): The Wealth Effect in Empirical Life-cycle Aggregate Consumption Equations. Economic Quarterly, 87, No. 2, pp. $45-68$.

MUELLER, L. (2019): Women and the Egyptian Revolution: Engagement and Activism during the 2011 Arab Uprisings. Journal of Modern African Studies, 57, No. 1, pp. 164 - 165. Available at: 〈https://doi.org/10.1017/9781108378468.007>.

OECD (2009): National Accounts of OECD Countries 2009. Vol. I. Main Aggregates, OECD Publishing. Paris: Organisation for Economic Co-operation and Development. Available at: <http://www.oecd.org/newsroom/43125523.pdf>.

PESARAN, M. H. (2020): General Diagnostic Tests for Cross-Sectional Dependence in Panels. Empirical Economics, 5, No. 60, pp. 13 - 50. Available at: <https://doi.org/10.1007/s00181-020-01875-7>.

PESARAN, M. H. - YAMAGATA, T. (2008): Testing Slope Homogeneity in Large Panels. Journal of Econometrics, 142, No. 1, pp. 50 - 93. Available at: <https://doi.org/ 10.1016/j.jeconom.2007.05.010>.

PHIPPS, S. A. - BURTON, P. S. (1998): What's Mine is Yours? The Influence of Male and Female Incomes on Patterns of Household Expenditure. Economica, 65, No. 260, pp. 599 - 613. Available at: <https://doi.org/10.2307/2555190>.

PISCHKE, J. S. (1991): Individual Income, Incomplete Information and Aggregate Consumption. [Working Papers.] Available at: <https://core.ac.uk/reader/39350910>.

RAZ-YUROVICH, L. (2010): Men's and Women's Economic Activity and First Marriage: Jews in Israel, 1987 - 1995. Demographic Research, 22, No. 29, pp. 933 - 964. Available at: <https://doi.org/10.4054/DemRes.2010.22.29>.

ROBERTS, C. (2014): Consuming Mass Fashion: The Impact of the Purchasing Power of Young Working Class Women on Ready-to-wear Manufacture and Retail. AAS/Division for Planetary Sciences Meeting. AAS/Division for Planetary Sciences Meeting Abstracts. Available at: <https://eprints.mdx.ac.uk/17139/>. 
SALMERÓN, M. H. - ROMERO-ÁVILA, D. (2014): Convergence in Output and Its Sources among Industrialised Countries: A Cross-country Time-series Perspective. Switzerland: Springer Briefs in Economics.

SARAFIDIS, V. - YAMAGATA, T. - ROBERTSON, D. (2009): A Test of Cross Section Dependence for a Linear Dnamic Panel Model with Regressors. Journal of Econometrics, 148, No. 2, pp. 149 - 161. Available at: 〈https://doi.org/10.1016/j.jeconom.2008.10.006>.

SCHMEER, K. (2005): Married Women's Resource Position and Household Food Expenditures in Cebu, Philippines. Journal of Marriage and Family, 67, No. 2, pp. 399 - 409. Available at: <https://doi.org/10.1111/j.0022-2445.2005.00124.x>.

SHOTICK, J. A. (2015): Trade-off of Expenditures for Food Away from Home for the Wife's Housework Time by Employment Status. In: Proceedings of the 1999 Academy of Marketing Science (AMS) Annual Conference, pp. 6 - 10. Springer, Cham. Available at: <https://doi.org/10.1007/978-3-319-13078-1_2>.

SOBERON-FERRER, H. - DARDIS, R. (1991): Determinants of Household Expenditures for Services. Journal of Consumer Research, 17, No. 4, pp. 385 - 397. Available at: <https://doi.org/10.1086/208565>.

SVALERYD, H. (2009): Women's Representation and Public Spending. European Journal of Political Economy, 25, No. 2, pp. 186 - 198. Available at: <https://doi.org/10.1016/j.ejpoleco.2008.12.004>.

WAMOYI, J. - BALVANZ, P. - GICHANE, M. W. - MAMAN, S. - MUGUNGA, S. - MAJANI, E. - PETTIFOR, A. (2020): Decision-making and Cash Spending Patterns of Adolescent Girls and Young Women Participating in a Cash-Transfer Intervention in Tanzania: Implications for Sexual Health. Global Public Health, 15, No. 4, pp. 587 - 597. Available at: <https://doi.org/10.1080/17441692.2019.1692891>.

WATSON, N. - WOODEN, M. (2013): Adding a Top-up Sample to the Household, Income and Labour Dynamics in Australia Survey. Australian Economic Review, 46, No. 4, pp. 489 - 498. Available at: 〈https://doi.org/10.1111/1467-8462.12027>.

WEBER, W. E. (1970): The Effect of Interest Rates on Aggregate Consumption. The American Economic Review, 60, No. 4, pp. $591-600$.

WESTERLUND, J. (2008): Panel Cointegration Tests of the Fisher Effect. Journal of Applied Econometrics, 23, No. 2, pp. 193 - 233. Available at: 〈https://doi.org/10.1002/jae.967〉.

WOOLDRIDGE, J. M. (2002): Econometric Analysis of Cross Section and Panel Data. Cambridge, MA: MIT Press. 108 p. 